\title{
Entrepreneurial Orientation and Financial Resources Availability as Determinants of Firms' Growth
}

\author{
Mario Mustilli, Eugenio D’Angelo, Francesco Campanella, Domenico Graziano \\ Department of Legal and Economic Science, Università Telematica Pegaso, Naples, Italy \\ Email: eugenio.dangelo@unipegaso.it
}

How to cite this paper: Mustilli, M., D'Angelo, E., Campanella, F. and Graziano, D. (2017) Entrepreneurial Orientation and Financial Resources Availability as Determinants of Firms' Growth. Modern Economy, 8, 298-307.

https://doi.org/10.4236/me.2017.82021

Received: February 3, 2017

Accepted: February 21, 2017

Published: February 24, 2017

Copyright $\odot 2017$ by authors and Scientific Research Publishing Inc. This work is licensed under the Creative Commons Attribution International License (CC BY 4.0).

http://creativecommons.org/licenses/by/4.0/

\begin{abstract}
The purpose of this empirical paper is to investigate the determinants of firms' growth during different financial cycles. In particular, we analyze the relationship between firms' growth and their entrepreneurial orientation. In addition, we investigate how firms' financial constraints moderate the relation between entrepreneurial orientation and growth before and during financial crisis. We test our hypotheses with an OLS regression model run on a sample of 382 European listed firms between 2003 and 2012. We found that entrepreneurial orientation is a determinant of firms' growth and that during the period of crisis this relation is slightly exacerbated. Furthermore, we found that financial constraints only slightly attenuate the entrepreneurial orientation prediction of growth, which may mean that when firm is more financial constraint could be forced to increase its entrepreneurial orientation in order to maintain a higher growth rate.
\end{abstract}

\section{Keywords}

Entrepreneurial Orientation, Financial Constraints, Growth

\section{Introduction}

The European financial crisis and the sovereign debt crisis, both started in 2008, have exacerbated the importance of studying the interaction between the financial cycle and the business cycle. When financial markets are in a crisis period, it is obviously more difficult for firms to get adequate financial resources to implement their growth strategies. Firms that usually finance their activities with banks' loans may find harder their access to capital, mostly due to banks' financial constraints (according to Basel accords and to the rising amount of nonperforming loans). On the other hand, when a firm wishes to get equity re- 
sources from financial markets, it may suffer the timing problem, which is connected to the opportunity to get higher financial resources from the markets in case of positive financial cycles. This is why financial cycles and the real economy cycles are two sides of the same coin that may be studied examining their interactions.

When the financial cycle is negative, firms may react in different ways. Some firms may be discouraged to invest because their growth opportunities are essentially connected to their availability of financial resources, but some other, more innovative and proactive, may try to catch growth opportunities relying on their entrepreneurial capacity which may be fostered by the financial constriction.

This empirical article examines whether the importance of firms' entrepreneurial orientation, as a determinant of growth, changes during different financial cycles. In addition, we investigate the effect of resources availability, which may change during different financial cycles, in moderating the effects of firms' entrepreneurial orientation on growth.

The paper consists of four more sections. In the first section we describe our conceptual framework, according to the main contributions in the field, and the hypotheses. In the second section we represent the method and describe the sample. In the third section we provide our findings and their explanation. We finally conclude, in the last section, summing up the main contribution of the paper, its limitations and possible future streams of research.

\section{Theoretical Framework and Research Hypotheses}

While some studies demonstrate that small and medium entrepreneurs are more concerned about profit maximization, the ability of firms to catch growth opportunity remain an important topic, as far as growth is often a synonymous of firms' ability to survive [1].

Furthermore, studying growth and its determinants is becoming more important in a period of crisis, since in these periods firms are more likely, not only to fail, but also to catch new profitable business opportunities.

In this context the ability of firms to survive and catch new business opportunities is strictly connected to their attitude to be entrepreneurial. Our definition of entrepreneurial orientation is consistent with the one given by Miller (1983) [2]. This Author argues that an entrepreneurial firm "engages in product-market innovation, undertakes somewhat risky ventures and is first to come up with proactive innovations, beating competitors to the punch".

According to previous studies [3], we consider an important dimension of firms' entrepreneurial management, their orientation towards growth; therefore we posit our first hypothesis as follows:

H.1) The entrepreneurial Orientation is a determinant of firms' growth

Since we believe that firms have an idiosyncratic way to deal with crisis and that crisis may also be an opportunity for proactive firms, we think that, even if firms may grow more in a stable environment [4], during an adverse financial cycle some firm may over perform and some other may fail their growth target. 
For these reasons we hypothesize our second statement as follows:

H.2) The financial cycle is not itself a negative determinant of firms' growth

We believe that in order to react to financial crisis, firms should raise their entrepreneurial orientation. Even if, when a firm is dealing with an adverse context, it may be harder to set up riskier business activities, in order to gain higher growth rates and therefore higher survival probability, we think, consistently with previous studies [5], firms should try to be more entrepreneurial during adverse financial cycles. In other words, the more the financial cycles are risky, the more firms should take risks. Therefore we formulate our third hypotheses as follows:

H.3) The relationship between entrepreneurial orientation and firms' growth is higher during the crisis financial cycle

However, the entrepreneurial orientation of a firm may be affected by firms' resources availability with particular regard to financial resources. As far as, during different financial cycles, firms may have different financial resources, the entrepreneurial orientation of a firm may be differently supported by finance.

Even if a large amount of studies [6] demonstrate that the entrepreneurial orientation is highly resource consuming, it doesn't mean that financially constrained firms should be less entrepreneurial. Conversely, we think that financial constraints may exacerbate the relation between entrepreneurial orientation and firms' growth. Therefore we formulate our last hypothesis:

H.4) Financial constraints increase firms' entrepreneurial orientation as determinant of growth

\section{Materials and Methods}

The initial sample involved all listed European non-financial firms, which have a number of employees between 50 and 250, because we were interested in small and medium enterprises in order to catch higher growth rates. The number of firms obtained in this way was 445 . After restricting our sample to accessible data from the period 2002 to 2012 and controlling for variables normality, our sample was reduced to 382 firms. Even if our longitudinal study has been conducted over a ten-year period (2003-2012), we needed data for 2002 as well in order to calculate 2003 variations for some variables such as, for instance, the growth rate. Data, both accounting and market once, were gathered from Thomson Reuters Eikon and were log-transformed in the case of total asset measurement. We used SPSS 17.0 to calculate both the correlation matrix and the OLS models.

Model 1:

In response to the first and to the second research question (H.1 and H.2), we elaborated the following model:

$$
\mathrm{g}=\alpha+\beta_{1} \mathrm{EO}+\beta_{2} \text { Crisis }+\beta_{3} \text { Country }+\beta_{4} \text { Size }+\varepsilon
$$

Dependent Variable: 
We measured growth $(g)$ using sales growth, consistently with other similar studies [7]. Total assets variation, which could also have been used to capture size variation, could be too endogenous and lead us to multicollinearity problems, particularly when using financial constraints as an independent variable.

Independent Variables:

We measured entrepreneurial orientation (EO) according to Miller and LeBreton-Miller (2011) [8]. Therefore we considered entrepreneurial orientation as a joint function of three measures: innovation, proactiveness and risk taking. Innovation was measured dividing research and development expenses by total sales. This because we agree in considering more innovative those firms that invests a higher amount of money in research and development. Proactiveness was measured using the profit-reinvesting rate, which is the percentage of annual earning reinvested in the company. We used this measures because, once again consistently with Miller and Le Breton-Miller (2011) [8], we do think that reinvesting profits in the company, instead of paying higher dividends, may be a proxy of investing opportunities that firms are willing to catch. Risk taking was measured calculating the idiosyncratic return volatility (over 252 trading days per year). The idiosyncratic return volatility is the volatility of daily abnormal equity returns measured over 252 days. The daily abnormal equity return is calculated as the difference between the firm daily raw equity return and the value-weighted daily market return. This measure is consistent with previous literature about risk tanking measurement because it represents the unsystematic risk. In other words it represents the fluctuation in the price of stocks that could be not attributed to macroeconomic factors, which are usually measured with the Betas coefficients.

We used a dummy variable (Crisis) to indicate if data were observed in a period of crisis or in a period before crisis. The Crisis variable, therefore, is set equal to 1 if data are observed in a crisis period and 0 in the other cases. We identified the pre-crisis period in 5 years before 2008 (2003-2007) and the crisis period in the next 5 years (2008-2012).

Control Variables:

We used two control variables. We controlled for size, measuring it with the lognormal transformation of total asset and we controlled for country measuring it with the national GDP annual variation.

\section{Model 2:}

The second step of our study was put in place to investigate the determinants of growth indifferent financial cycle, assuming that the financial cycle influences firms' financial resource availability. Therefore our analysis, tested both in the crisis period and in the pre-crisis period, in response to the third and to the fourth research questions (H.3 and H.4) was conducted by verifying the statistical significance of the following model:

$$
\mathrm{g}=\alpha+\beta_{1} \mathrm{EO}+\beta_{2} \mathrm{KZ} \text { score }+\beta_{3} \text { InteractionEOKZ }+\beta_{4} \text { Country }+\beta_{5} \mathrm{Size}+\varepsilon
$$

Dependent variable:

Our dependent variable remains the same used in the first model $(\mathrm{g})$. 
Independent variables:

We measured the entrepreneurial orientation in the same way of the first model (EO). We measured firms' resource availability following Kaplan and Zingales (1997) [9]. Therefore we measured firms' financial constraints as a joint function (KZ score) of 5 variables such as dividends paid, stock of cash and cash equivalents, cash flows, leverage and Tobin's $\mathrm{Q}$. We estimate the $\mathrm{KZ}$ score as a measure of financial constraints using Kaplan and Zingales Betas coefficients, as in previous studies [10].

$\mathrm{KZ}$ score $=-1.001909 *(\mathrm{CASH}$ FLOW $/ \mathrm{K})+0.2826289 *(\mathrm{Q})+3,139193 *(\mathrm{DEBT} / \mathrm{K})$ $-39.3678 *(\mathrm{DIVIDENDS} / \mathrm{K})-1.314759 *(\mathrm{CASH} / \mathrm{K})$

The KZ score indicates a negative relationship between financial constraints and operating cash flow divided by total capital, dividends divided by total capital and cash and cash equivalents divided by total capital. On the other hand it assumes a positive predictor for market to book ratio and for debt to total capital.

Furthermore, we defined another independent variable as the interaction between the KZ score and the entrepreneurial orientation (Interaction EOKZ). We obtained this variable multiplying the $\mathrm{KZ}$ score by the entrepreneurial orientation, in order to measure if any effect on growth is given by the interaction between the entrepreneurial orientation and firms' resources availability.

We finally controlled for size and country as in the first model.

\section{Results and Discussion}

Before proceeding to comment our results, in order to provide a response to the four research questions, is appropriate to show the analysis of correlations between the variables, using the correlation matrix (Table 1).

Table 1. Correlation matrix (model 1$)$.

\begin{tabular}{|c|c|c|c|c|c|c|}
\hline & & $\mathrm{g}$ & Crisis & $\mathrm{EO}$ & Size & Country \\
\hline \multirow[t]{3}{*}{$\mathrm{g}$} & Pearson Correlation & 1 & 0.18 & 1.44 & -0.003 & 0.041 \\
\hline & Sig. (2-tailed) & & 0.272 & 0.000 & 0.849 & 0.011 \\
\hline & $\mathrm{N}$ & 3819 & 3819 & 3819 & 3819 & 3819 \\
\hline \multirow[t]{3}{*}{ Crisis } & Pearson Correlation & 0.018 & 1 & 0.105 & -0.046 & -0.195 \\
\hline & Sig. (2-tailed) & 0.272 & & 0 & 0.004 & 0.000 \\
\hline & $\mathrm{N}$ & 3819 & 3819 & 3819 & 3819 & 3819 \\
\hline \multirow[t]{3}{*}{$\mathrm{EO}$} & Pearson Correlation & 0.144 & 0.105 & 1 & -0.383 & -0.033 \\
\hline & Sig. (2-tailed) & 0.000 & 0.000 & & 0 & 0.041 \\
\hline & $\mathrm{N}$ & 3819 & 3819 & 3819 & 3819 & 3819 \\
\hline \multirow[t]{3}{*}{ Size } & Pearson Correlation & -0.003 & -0.46 & -0.383 & 1 & -0.037 \\
\hline & Sig. (2-tailed) & 0.849 & 0.004 & 0.000 & & 0.023 \\
\hline & $\mathrm{N}$ & 3819 & 3819 & 3819 & 3819 & 3819 \\
\hline \multirow[t]{3}{*}{ Country } & Pearson Correlation & 0.041 & -0.195 & -0.033 & -0.037 & 1 \\
\hline & Sig. (2-tailed) & 0.011 & 0.000 & 0.041 & 0.023 & \\
\hline & $\mathrm{N}$ & 3819 & 3819 & 3819 & 3819 & 3819 \\
\hline
\end{tabular}

Source: Author's calculation on data collected from data stream. 
In order to investigate the causality relationship between the variables under investigation and provide responses to the first research questions, a regression analysis on the first model was performed. The results of our OLS analysis and the ANOVA test are reported in Table 4. Our analysis show that the model can explain the $2.6 \%$ of the variance of the dependent variable, while the results of the ANOVA test are an F-value of 26,040 and a significance value below 0.01 (Table 2).

As far as the analysis of the regression coefficients is concerned, it was found that the entrepreneurial orientation is a positive predictor of firms' growth.

Consistently with our first hypothesis, we can say that firms with a higher entrepreneurial orientation, which is connected with a higher rate of innovation, of proactiveness and of risk taking, may have an higher growth rate. Therefore we can confirm hypothesis 1.

On the other hand we didn't find any significance in the predictors of crisis. This means that any given change in the firms' growth rate is not due to the financial cycle itself. Therefore we can confirm hypothesis 2 .

Furthermore we found a significant relationship between the dependent variable and both the controlling variables, this means that further analysis should be conducted in order to deeply investigate the causality effects in subgroups. Literature in the field usually controls for the age of the firms, because younger firms, which are more likely to have smaller dimensions, usually have higher growth rates.

Even if the financial cycle is not significantly related to growth rates, this doesn't mean that changes in the growth rates experienced by firms of the samples hadn't change when their resource availability had change in the different period of analysis. For this reason, we first analyze the correlation between variables in the pre-crisis period and in the crisis period (Table 3 and Table 4), than we ran a second and a third OLS regression to verify whether there was a nexus of causality between firms' financial constraints and growth and, moreover, if any given change in firms' financial constraints may influence the effect of

Table 2. Regression analysis (model 1).

\begin{tabular}{|c|c|c|c|}
\hline \multirow{2}{*}{ Model } & \multicolumn{3}{|c|}{ Growth } \\
\hline & \multicolumn{2}{|c|}{ Standardized coefficients } & T-statistic \\
\hline $\mathrm{EO}$ & \multicolumn{2}{|c|}{$0.17^{\star *}$} & 6.78 \\
\hline Crisis & \multicolumn{2}{|c|}{0.013} & 0.661 \\
\hline Size & \multicolumn{2}{|c|}{$0.064^{* *}$} & 3.702 \\
\hline Country & \multicolumn{2}{|c|}{$0.052^{* *}$} & 3.159 \\
\hline \multirow{2}{*}{ Model summary } & R-Square & \multicolumn{2}{|c|}{ Adjusted R-Square } \\
\hline & 0.027 & \multicolumn{2}{|c|}{0.026} \\
\hline \multirow{2}{*}{ ANOVA } & \multicolumn{2}{|c|}{$\mathrm{F}$} & \\
\hline & \multicolumn{2}{|c|}{$26.040^{\star *}$} & \\
\hline \multicolumn{4}{|l|}{ Sign. level: $1 \%\left({ }^{* *}\right) ; 5 \%\left(^{*}\right)$} \\
\hline
\end{tabular}

Source: Author's calculation on data collected from data stream. 
Table 3. Correlation matrix (model 2-in the pre-crisis sub sample).

\begin{tabular}{|c|c|c|c|c|c|c|c|}
\hline & & $\mathrm{g}$ & $\mathrm{EO}$ & Country & Size & $\mathrm{KZ}$ score & $\begin{array}{c}\text { Interaction } \\
\text { EOKZ }\end{array}$ \\
\hline \multirow[t]{3}{*}{$\mathrm{g}$} & $\begin{array}{l}\text { Pearson } \\
\text { Correlation }\end{array}$ & 1 & 0.148 & 0.057 & -0.048 & 0.087 & 0.122 \\
\hline & Sig. (2-tailed) & & 0.000 & 0.012 & 0.034 & 0.000 & 0.000 \\
\hline & $\mathrm{N}$ & 1916 & 1916 & 1916 & 1916 & 1916 & 1916 \\
\hline \multirow[t]{3}{*}{$\mathrm{EO}$} & $\begin{array}{l}\text { Pearson } \\
\text { Correlation }\end{array}$ & 0.148 & 1 & 0.018 & -0.466 & 0.316 & 0.679 \\
\hline & Sig. (2-tailed) & 0.000 & & 0.431 & 0.000 & 0.000 & 0.000 \\
\hline & $\mathrm{N}$ & 1916 & 1916 & 1916 & 1916 & 1916 & 1916 \\
\hline \multirow[t]{3}{*}{ Country } & $\begin{array}{l}\text { Pearson } \\
\text { Correlation }\end{array}$ & 0.057 & 0.018 & 1 & -0.054 & -0.006 & -0.014 \\
\hline & Sig. (2-tailed) & 0.012 & 0.431 & & 0.018 & 0.792 & 0.530 \\
\hline & $\mathrm{N}$ & 1916 & 1916 & 1916 & 1916 & 1916 & 1916 \\
\hline \multirow[t]{3}{*}{ Size } & $\begin{array}{l}\text { Pearson } \\
\text { Correlation }\end{array}$ & -0.048 & 0.466 & -0.054 & 1 & -0.608 & -0.476 \\
\hline & Sig. (2-tailed) & 0.034 & 0.000 & 0.018 & & 0.000 & 0.000 \\
\hline & $\mathrm{N}$ & 1916 & 1916 & 1916 & 1916 & 1916 & 1916 \\
\hline \multirow[t]{3}{*}{ KZ score } & $\begin{array}{l}\text { Pearson } \\
\text { Correlation }\end{array}$ & 0.087 & 0.316 & -0.006 & -0.608 & 1 & 0.671 \\
\hline & Sig. (2-tailed) & 0.000 & 0.000 & 0.792 & 0.000 & & 0.000 \\
\hline & $\mathrm{N}$ & 1916 & 1916 & 1916 & 1916 & 1916 & 1916 \\
\hline \multirow[t]{3}{*}{$\begin{array}{c}\text { Interaction } \\
\text { EOKZ }\end{array}$} & $\begin{array}{c}\text { Pearson } \\
\text { Correlation }\end{array}$ & 0.122 & 0.689 & -0.014 & -0.476 & 0.671 & 1 \\
\hline & Sig. (2-tailed) & 0.000 & 0.000 & 0.530 & 0.000 & 0.000 & \\
\hline & $\mathrm{N}$ & 1916 & 1916 & 1916 & 1916 & 1916 & 1916 \\
\hline
\end{tabular}

Source: Author's calculation on data collected from data stream.

the entrepreneurial orientation on firms' growth.

Both models, pre crisis and crisis, were statistically significant. Specifically, our models show an adjusted R2 around 3\%, while the results of the ANOVA test are an F-value of 12,025 and 12,756 with a significance value below 0.01 (Table 5).

Our models confirm the sign of the causality relationship between the entrepreneurial orientation and firms' growth. In both cases, as in model 1, higher entrepreneurial orientation may lead to higher firms' growth rates. However the strength of the relation is slightly higher in the crisis period. This is why hypothesis 3 can be confirmed.

On the other hand, when it comes to the discussion about resource availability and growth, we found ambiguous results, as often has been found in empirical previous studies [11]. In the pre-crisis period we found a weak but positive and significant relationship between financial constraints and companies growth. This means that growth may be higher in firms with less financial resources. We didn't find the same analyzing the relation in the crisis period. Conversely, we 
Table 4. Correlation matrix (model 2-in the crisis sub sample).

\begin{tabular}{|c|c|c|c|c|c|c|c|}
\hline & & g & $\mathrm{EO}$ & Country & Size & $\mathrm{KZ}$ score & $\begin{array}{c}\text { Interaction } \\
\text { EOKZ }\end{array}$ \\
\hline \multirow[t]{3}{*}{$\mathrm{g}$} & $\begin{array}{l}\text { Pearson } \\
\text { Correlation }\end{array}$ & 1 & 0.139 & 0.058 & 0.04 & -0.016 & 0.037 \\
\hline & Sig. (2-tailed) & & 0.000 & 0.011 & 0.081 & 0.490 & 0.106 \\
\hline & $\mathrm{N}$ & 1903 & 1903 & 1903 & 1903 & 1903 & 1903 \\
\hline \multirow[t]{3}{*}{$\mathrm{EO}$} & $\begin{array}{l}\text { Pearson } \\
\text { Correlation }\end{array}$ & 0.139 & 1 & 0.018 & -0.311 & 0.224 & 0.608 \\
\hline & Sig. (2-tailed) & 0.000 & & 0.432 & 0.000 & 0.000 & 0.000 \\
\hline & $\mathrm{N}$ & 1903 & 1903 & 1903 & 1903 & 1903 & 1903 \\
\hline \multirow[t]{3}{*}{ Country } & $\begin{array}{l}\text { Pearson } \\
\text { Correlation }\end{array}$ & 0.058 & 0.018 & 1 & -0.044 & 0.001 & 0.011 \\
\hline & Sig. (2-tailed) & 0.011 & 0.432 & & 0.053 & 0.978 & 0.624 \\
\hline & $\mathrm{N}$ & 1903 & 1903 & 1903 & 1903 & 1903 & 1903 \\
\hline \multirow[t]{3}{*}{ Size } & $\begin{array}{l}\text { Pearson } \\
\text { Correlation }\end{array}$ & 0.04 & -0.311 & -0.044 & 1 & -0.499 & -0.375 \\
\hline & Sig. (2-tailed) & 0.081 & 0.000 & 0.053 & & 0.000 & 0.000 \\
\hline & $\mathrm{N}$ & 1903 & 1903 & 1903 & 1903 & 1903 & 1903 \\
\hline \multirow[t]{3}{*}{ KZ score } & $\begin{array}{c}\text { Pearson } \\
\text { Correlation }\end{array}$ & -0.016 & 0.224 & 0.001 & -0.499 & 1 & 0.625 \\
\hline & Sig. (2-tailed) & 0.490 & 0.000 & 0.978 & 0.000 & & 0.000 \\
\hline & $\mathrm{N}$ & 1903 & 1903 & 1903 & 1903 & 1903 & 1903 \\
\hline \multirow[t]{3}{*}{$\begin{array}{c}\text { Interaction } \\
\text { EOKZ }\end{array}$} & $\begin{array}{l}\text { Pearson } \\
\text { Correlation }\end{array}$ & 0.037 & 0.608 & 0.011 & -0.375 & 0.625 & 1 \\
\hline & Sig. (2-tailed) & 0.106 & 0.000 & 0.624 & 0.000 & 0.000 & \\
\hline & $\mathrm{N}$ & 1903 & 1903 & 1903 & 1903 & 1903 & 1903 \\
\hline
\end{tabular}

Source: Author's calculation on data collected from data stream.

Table 5. Regression analysis (model 2).

\begin{tabular}{|c|c|c|c|c|c|c|}
\hline \multirow[b]{2}{*}{ Model } & \multicolumn{3}{|c|}{ Growth PRE-CRISIS } & \multicolumn{3}{|c|}{ Growth CRISIS } \\
\hline & \multicolumn{2}{|c|}{$\begin{array}{c}\text { Standardized } \\
\text { coefficients }\end{array}$} & T-statistic & \multicolumn{2}{|c|}{$\begin{array}{c}\text { Standardized } \\
\text { coefficients }\end{array}$} & T-statistic \\
\hline $\mathrm{EO}$ & \multicolumn{2}{|c|}{$0.165^{\star *}$} & 4.794 & \multicolumn{2}{|c|}{$0.204^{\star *}$} & 6.754 \\
\hline $\mathrm{KZ}$ score & \multicolumn{2}{|c|}{$0.095^{*}$} & 2.555 & \multicolumn{2}{|c|}{0.03} & 0.906 \\
\hline $\begin{array}{c}\text { Interaction } \\
\text { EOKZ }\end{array}$ & \multicolumn{2}{|c|}{-0.13} & -0.313 & \multicolumn{2}{|c|}{$-0.071^{\star}$} & -1.922 \\
\hline Size & \multicolumn{2}{|c|}{0.083} & 2.68 & \multicolumn{2}{|c|}{$0.094^{\star *}$} & 3.504 \\
\hline Country & \multicolumn{2}{|c|}{0.059} & 2.614 & \multicolumn{2}{|c|}{$0.06^{\star *}$} & 2.634 \\
\hline \multirow[t]{2}{*}{$\begin{array}{c}\text { Model } \\
\text { summary }\end{array}$} & R-Square & $\begin{array}{l}\text { Adj } \\
\text { R-S }\end{array}$ & & R-Square & \multicolumn{2}{|c|}{$\begin{array}{l}\text { Adjusted } \\
\text { R-Square }\end{array}$} \\
\hline & 0.31 & & & 0.033 & 0. & \\
\hline \multirow{2}{*}{ ANOVA } & \multicolumn{2}{|c|}{$\mathrm{F}$} & \multicolumn{4}{|c|}{$\mathrm{F}$} \\
\hline & \multicolumn{2}{|c|}{$12.025^{\star *}$} & & \multicolumn{2}{|c|}{12.756} & \\
\hline \multicolumn{4}{|c|}{ Sign. level: $1 \%\left({ }^{*}\right) ; 5 \%\left({ }^{*}\right)$} & & & \\
\hline
\end{tabular}

Source: Author's calculation on data collected from data stream. 
didn't find any significant relation between the interaction variable and firms growth in the pre-crisis period, but we did find a negative and significant relationship in the crisis period. This means that if firms face financial constraints, the entrepreneurial orientation as a determinant of growth is lower.

In order to verify the economic magnitude of this effect we analyzed the standard deviation of the entrepreneurial orientation (it has been measured 1286) and we found that the main effect of the entrepreneurial orientation on growth is that an unitary increase in the standard deviation of the entrepreneurial orientation is associated with an increase of $22 \%$ of growth, but in the crisis period the financial constraints lowers this association down to $13 \%$. Once again the relation between both control variables and the dependent variable was statistically significant. Therefore we can only partially confirm hypothesis 4 .

\section{Conclusions}

With this paper, we confirm that the entrepreneurial orientation of a firm is a determinant of its growth, no matter if we are in a period of financial crisis or not. We demonstrate that the financial cycle doesn't lead to significantly different changes in growth rates, but on the other hand, we found that the relationship between entrepreneurial orientation and growth is higher during adverse financial cycles.

However, our findings show that in a period of crisis, when firms may face a higher financial constraint, having lower resource availability only slightly influences the relation between the entrepreneurial orientation and growth. These results may lead us to give a substantial contribution to the existing literature, particularly for the social implication that this paper has. We can say that entrepreneurial orientation may be more important than financial resources availability in generating firms' growth, particularly when firms are facing a challenging crisis period. For this reasons when a country is facing a crisis period, government should pay attention to the entrepreneurial orientation of firms in order to predict what kind of impact on growth the financial crisis may have [12]. If more entrepreneurial firms populate the country, this may attenuate the financial constriction. Conversely, if firms are less entrepreneurial, government should substitute financial markets in providing resources and avoid gross product stagnation, which may result in unemployment and low deflation. Obviously our study has some limitation and could be more improved through further analysis. For instance, as far as we have found a statistically significant relation with the control variables, we may study the same effects in subgroups, running regressions in homogenous samples according to their geographic origin and their size. Italian firms, for example, may have faced a harder period of crisis if compared to French or other ones. What could be really interesting is to study the different way of reaction of Italian and other firms in terms of the effect on growth of their entrepreneurial orientation. Furthermore, in this paper we examine small and medium enterprises, but since, in the crisis period, the size-controlling variable is significant, other analysis concerning the impact of the entrepreneurial 
orientation on growth might be needed. For example, in a future research, it could be found that smaller firms may not be capable to substitute financial resources with their entrepreneurial capabilities in the same ways that bigger firms are able to do.

\section{References}

[1] Phillips, B. and Kirchhoff, B. (1989) Formation, Growth and Survival; Small Firm Dynamics in the US Economy. Small Business Economics, 1, 65-67. https://doi.org/10.1007/BF00389917

[2] Miller, D. (1983) The Correlates of Entrepreneurship in Three Types of Firms. Management Science, 29, 770-792. https://doi.org/10.1287/mnsc.29.7.770

[3] Brown, T., Davidsson, P. and Wiklund, J. (2001) An Operationalization of Stevenson's Conceptualization of Entrepreneurship as Opportunity-Based Firm Behavior. Strategic Management Journal, 22, 953-968. https://doi.org/10.1002/smj.190

[4] Baum, J.R., Locke, E.A. and Smith, K.G. (2001) A Multidimensional Model of Venture Growth. Academy of Management Journal, 44, 292-303. https://doi.org/10.2307/3069456

[5] Lumpkin, G.T. and Dess, G. (2001) Linking Two Dimensions of Entrepreneurial Orientation to Firm Performance: The Moderating Role of Environment and Industry Life Cycle. Journal of Business Venturing, 16, 429-451. https://doi.org/10.1016/S0883-9026(00)00048-3

[6] Covin, J.G. and Slevin, D.P. (1991) A Conceptual Model of Entrepreneurship as a Firm Behavior. Entrepreneurship Theory and Practice, 16, 7-25.

[7] Moreno, A.M. and Casillas, J.C. (2008) Entrepreneurial Orientation and Growth of SMEs: A Causal Model. Entrepreneurship Theory and Practice, 32, 507-528. https://doi.org/10.1111/j.1540-6520.2008.00238.x

[8] Miller, D. and Le Breton-Miller, I. (2011) Governance, Social Identity, and Entrepreneurship Orientation in Closely Held Companies. Entrepreneurship Theory \& Practice, 35, 1051-1076. https://doi.org/10.1111/j.1540-6520.2011.00447.x

[9] Kaplan, S.N. and Zingales, L. (1997) Do Financing Constraints Explain Why Investment Is Correlated with Cash Flow? Quarterly Journal of Economics, 48, 65-91.

[10] Lamont, O., Polk, C. and Saa-Requejo, J. (2001) Financial Constraints and Stock Returns. The Review of Financial Studies, 14, 529-554. https://doi.org/10.1093/rfs/14.2.529

[11] Wiklund, J. and Shepherd, D. (2005) Entrepreneurial Orientation and Small Business Performance: A Configurational Approach. Journal of Business Venturing, 20, 71-91. https://doi.org/10.1016/j.jbusvent.2004.01.001

[12] Campanella, F., Del Giudice, M. and Della Peruta, M.R. (2013) The Role of Information in the Credit Relationship. Journal of Innovation and Entrepreneurship, 2, 1-17. 
Submit or recommend next manuscript to SCIRP and we will provide best service for you:

Accepting pre-submission inquiries through Email, Facebook, LinkedIn, Twitter, etc. A wide selection of journals (inclusive of 9 subjects, more than 200 journals)

Providing 24-hour high-quality service

User-friendly online submission system

Fair and swift peer-review system

Efficient typesetting and proofreading procedure

Display of the result of downloads and visits, as well as the number of cited articles Maximum dissemination of your research work

Submit your manuscript at: http://papersubmission.scirp.org/

Or contact me@scirp.org 